\title{
PENGGUNAAN MEDIA VIDEO SPARKOL TERHADAP KEMAMPUAN BERPIKIR KREATIF SISWA PADA PEMBELAJARAN IPA DI SMP
}

\author{
Silvia Bella Yolanda, I Ketut Mahardika, Iwan Wicaksono \\ Program Studi Pendidikan IPA, Fakultas Keguruan dan Ilmu Pendidikan, Universitas Jember \\ Email: silviabella922@gmail.com
}

Diterima: 3 Juni 2021 Direvisi: 20 Agustus 2021 Disetujui: 30 September 2021

\begin{abstract}
Abstrak
Pembelajaran IPA saat ini siswa diharuskan memiliki keterampilan abad-21 salah satunya kemampuan berpikir kreatif. Namun, kemampuan berpikir kreatif siswa di Indonesia cenderung masih kurang. Solusi alternatif dalam mengatasi permasalahan tersebut yaitu melalui penggunaan media interaktif berupa video sparkol yang mampu memberikan gambaran materi lebih realistik, sehingga akan membangun rangsangan pemikiran kreatif siswa.Tujuan penelitian ini untuk mengkaji pengaruh penggunaan media video sparkol terhadap kemampuan berpikir kreatif siswa pada pembelajaran IPA di SMP menggunakan desain penelitian quasi eksperimen. Subjek penelitian ini adalah siswa kelas VIII SMPN 3 Rambipuji. Teknik pengambilan sampel menggunakan purposive sampling. Teknik pengumpulan data melalui pretest-posttest, observasi dan dokumentasi. Data yang diperoleh dianalisis menggunakan uji statistik berupa uji normalitas dan uji independent sample t-test. Namun setelah diberikan perlakuan hasil rata-rata post-test kelas eksperimen memiliki nilai yang lebih tinggi daripada kelas kontrol yakni dengan kategori tinggi. Hasil analisis post-test kemampuan berpikir kreatif menunjukkan nilai Sig. sebesar 0,000 $<0,05$ yang artinya terdapat perbedaan nilai rata-rata kemampuan berpikir kreatif siswa kelas kontrol dengan siswa kelas eksperimen, dimana nilai rata-rata kelas eksperimen lebih tinggi dari kelas kontrol, hal ini menunjukkan bahwa media video sparkol berpengaruh signifikan terhadap kemampuan berpikir kreatif siswa SMP.
\end{abstract}

Kata Kunci: Media Video Sparkol, Kemampuan Berpikir Kreatif.

\begin{abstract}
Learning science at this time students are required to have 21 st century skills, one of which is the ability to think creatively. However, students' creative thinking skills in Indonesia tend to be lacking. An alternative solution in overcoming these problems is through the use of interactive media in the form of sparkol videos which are able to provide a more realistic picture of the material, so that it will stimulate students' creative thinking. The purpose of this study was to examine the effect of using sparkol video media on students' creative thinking skills in science learning in junior high school using a quasi-experimental research design. The subjects of this study were students of class VIII SMPN 3 Rambipuji. The sampling technique used was purposive sampling. Data collection techniques through pretest-posttest, observation and documentation. The data obtained were analyzed using statistical tests in the form of normality test and independent sample t-test. However, after being given treatment, the average post-test result of the experimental class
\end{abstract}


Yolanda., Mahardika., Wicaksono. - Penggunaan Media Video Sparkol ...

had a higher value than the control class, namely the high category. The results of the post-test analysis of creative thinking skills showed the value of Sig. of $0.000<0.05$ which means that there is a difference in the average value of the creative thinking ability of the control class students with the experimental class students, where the average value of the experimental class is higher than the control class, this shows that the sparkol video media has a significant effect on thinking skills. creative junior high school students.

Keywords: Sparkol Video Media, Creative Thinking Ability.

\section{PENDAHULUAN}

IPA merupakan ilmu pengetahuan yang mempelajari mengenai cara mencari tahu tentang alam secara sistematis melalui kumpulan penguasaan pengetahuan berupa fakta, konsep, prinsip, hukum, dan teori yang sudah dibuktikan kebenarannya melalui suatu studi dari sekumpulan data hasil observasi, eksperimen, penyimpulan, teori maupun hasil dari suatu proses penemuan (Harefa \& Sarumaha, 2020). Pembelajaran IPA saat ini siswa diharuskan memiliki keterampilan abad-21 yang berfokus pada kemampuan siswa dalam memecahkan masalah. Pemecahan masalah tersebut mengarah pada kemampuan siswa dalam berpikir kreatif (Mayarni \& Yulianti, 2020).

Berpikir kreatif merupakan kemampuan siswa untuk bisa memecahkan permasalahan dengan menghasilkan ide berupa gagasan yang berkembang menjadi beberapa kemungkinan solusi untuk menyelesaikan permasalahan tersebut (Lailiyah \& Suliyanah, 2018). Indikator berpikir kreatif meliputi Indikator aspek fluency (kelancaran) yaitu siswa mampu memunculkan banyak ide dalam menjawab dan memecahkan permasalahan berupa pertanyaan yang diberikan oleh guru melalui gagasannya secara cepat dan lancar (Amtiningsih et al., 2016). Aspek flexibility (Keluwesan) yaitu kemampuan siswa dalam mendapatkan ide dari gagasan kreatifnya yang bervariasi melalui sudut pandang yang berbeda dari berbagai kategori objek dan permasalahan. Aspek elaboration (elaborasi) yaitu kemampuan siswa dalam mengajukan berbagai macam pendekatan untuk menyelesaikan pemecahan masalah. Serta aspek Originality (keaslian) yaitu siswa 
Yolanda., Mahardika., Wicaksono. - Penggunaan Media Video Sparkol ...

mampu untuk menghasilkan ide-ide yang tidak umum sehingga jawaban siswa tidak terpaku pada materi yang dijelaskan oleh guru dan buku pegangan siswa (Munandar, 2009).

Namun, kemampuan berpikir kreatif siswa di Indonesia cenderung masih kurang (Abdurrozak \& Jayadinata, 2016). Fakta di sekolah menunjukkan kemampuan berpikir kreatif siswa belum berkembang dengan baik (Susiningrum, 2018). Rendahnya kreativitas tersebut menjadi salah satu permasalahan pada bidang studi IPA, dimana dilihat dari hasil belajar siswa dalam menyelesaikan permasalahan pada soal dengan cara berpikir kreatif tergolong masih kurang optimal (Mulyadi et al., 2016).

Hal tersebut terjadi salah satunya karena masih adanya sekolah yang pembelajarannya mengutamakan metode ceramah guru, dan juga pembelajaran masih berorientasi dengan media ajar yang kurang interaktif seperti buku. Hal tersebut membuat kemampuan berpikir siswa kurang berkembang (Abdurrozak et al., 2016).
Seperti salah satu sekolah di Kabupaten Jember yakni SMP Negeri 3 Rambipuji, setelah dilakukan wawancara dengan guru IPA di sekolah tersebut kendala yang dialami dalam pembelajaran yaitu kurang optimalnya penggunaan media pembelajaran. Pada sekolah tersebut guru hanya menggunakan bahan ajar berupa media buku paket saja dan hanya sesekali menggunakan PPT, sehingga pembelajaran yang masih berorientasi dengan media ajar yang kurang interaktif tersebut membuat kemampuan berpikir siswa kurang berkembang (Abdurrozak et al., 2016). Untuk itu diperlukan media pembelajaran yang dapat membangun pemikiran siswa agar dapat berpikir kreatif dengan cara memvisualisasikan konsep yang abstrak menjadi terlihat lebih kongkrit (Permatasari et al., 2018).

Salah satu solusi alternatif yang dapat digunakan untuk membantu dalam mengkonkretkan visualisasi konsep IPA yang bersifat abstrak adalah melalui penggunaan media pembelajaran interaktif berupa video (Romadhoni et al., 2017). Salah satu media interaktif video yang bisa 
Yolanda., Mahardika., Wicaksono. - Penggunaan Media Video Sparkol ...

digunakan yaitu media video sparkol. Media video sparkol memiliki karakteristik sebagai media audiovisual yang mampu menggabungkan beberapa unsur media seperti teks, gambar, audio, animasi yang mampu memberikan stimulus sehingga materi dapat tersampaikan lebih efektif, media sparkol juga mampu meningkatkan kreativitas dan produktivitas siswa dalam proses pembelajaran (Wicaksono \& Indrawati, 2019: 23).

Video sparkol ini dapat membantu untuk memperjelas konsep-konsep materi yang abstrak serta mampu memberikan gambaran yang lebih realistik, yang akan membangun rangsangan pemikiran kreatif siswa (Wicaksono \& Indrawati, 2019).

Berdasarkan uraian tersebut, maka perlu adanya uji coba penggunaan media video sparkol untuk melihat pengaruhnya sebagai media interaktif terhadap kemampuan berpikir kreatif siswa pada pembelajaran IPA di SMP.

\section{METODE}

Penelitian ini dilakukan di SMPN 3 Rambipuji pada siswa kelas VIII pada topik tekanan zat dan penerapannya dalam kehidupan sehari-hari semester genap tahun ajaran 2020/2021.

Penentuan sampel penelitian ini menggunakan metode purposive sampling area yaitu pengambilan sampel berdasarkan kriteria tertentu yang sesuai dengan tujuan peneliti (Huwaida, 2019). Kriteria yang dimaksudkan yaitu sampel yang akan digunakan harus homogen dan siswa tersebut sebagian besar memiliki handphone. Peneliti akan menggunakan dua kelas untuk dijadikan sampel yaitu kelas kontrol dan kelas eksperimen. Kelas eksperimen diberikan perlakuan berupa pembelajaran menggunakan media video sparkol, sedangkan kelas kontrol pembelajaran tidak menggunakan media sparkol (tetapi menggunakan media PPT).

Jenis penelitian ini quasi eksperimen yaitu jenis penelitian dimana peneliti tidak melakukan randomisasi (acak) dalam penentuan subjek kelompok penelitian (Yusuf, 2017). Rancangan desain yang digunakan adalah non equivalent control group design dengan 
Yolanda., Mahardika., Wicaksono. - Penggunaan Media Video Sparkol ...

mengunakan dua kelas, yakni kelas pembelajaran diadakan post-test kontrol dan kelas eksperimen. untuk mengetahui pengaruh Langkah pertama diadakan pre-test pemberian perlakuan. Desain sebelum diberikan perlakuan untuk penelitian non equivalent control mengetahui kemampuan awal siswa group design dapat dilihat pada Tabel kemudian setelah dilakukan 1.

Tabel 1. Rancangan Desain Penelitian Non Equivalent Control Group Design

\begin{tabular}{cccc}
\hline Grup & Pre-test & Variabel Terikat & Post-test \\
\hline Eksperimen & $\mathrm{O}_{1}$ & $\mathrm{X}$ (treatment video sparkol) & $\mathrm{O}_{2}$ \\
Kontrol & $\mathrm{O}_{3}$ & - & $\mathrm{O}_{4}$ \\
\hline
\end{tabular}

Instrumen penelitian yang kemampuan berpikir kreatif, soal digunakan adalah tes berupa soal berupa pre-test dan post test. Setiap berindikator kemampuan berpikir soal diberikan rentang skor 1-4. kreatif. Pada penelitian ini ada 4 Adapun penilaian dan kriteria skor indikator kemampuan berpikir kreatif yang digunakan yaitu meliputi aspek fluency (kemampuan berpikir lancar), flexibility (kemampuan berpikir luwes), elaboration (kemampuan berpikir memerinci), dan originality (kemampuan berpikir orisinil) (Munandar, 2009).

Teknik analisis data pada penelitian ini menggunakan pengukuran kemampuan berpikir kreatif pada setiap aspek yakni (fluency, flexibility, originality, dan elaboration). Pada setiap butir soal menyangkut satu aspek indikator untuk kemampuan kreatif yaitu :

$$
P=\frac{A}{B} \times 100
$$

Dengan $P$ merupakan tingkat kemampuan berpikir kreatif tiap aspek, A adalah jumlah total skor per aspek yang diperoleh siswa, dan B adalah jumlah skor maksimum tiap aspek (Faelasofi, 2017).

Selanjutnya akan dikategorikan sesuai dengan kategori pada Tabel 2 (Arikunto, 2011). Data hasil post-test kemampuan berpikir kreatif selanjutnya dianalisis dengan menggunakan uji independent sample t-test untuk mengetahui pembelajaran 
Yolanda., Mahardika., Wicaksono. - Penggunaan Media Video Sparkol ...

setelah menggunakan media video terlebih dahulu di uji normalitas sparkol berpengaruh atau tidak untuk menentukan uji apa yang akan terhadap kemampuan berpikir kreatif. digunakan selanjutnya.

Sebelum dilakukan uji t-test, data

Tabel 2 Kriteria Kemampuan Berpikir Kreatif

\begin{tabular}{cc}
\hline Interval Nilai Kreatif Siswa & Kriteria kreatif \\
\hline $81-100$ & Sangat tinggi \\
\hline $61-80$ & Tinggi \\
\hline $41-60$ & Sedang \\
\hline $21-40$ & Rendah \\
\hline $0-20$ & Sangat rendah \\
\hline
\end{tabular}

\section{HASIL DAN PEMBAHASAN}

Populasi dalam penelitian ini seluruh kelas VIII yang terdiri dari 4 kelas. Hasil uji homogenitas menunjukkan hasil signifikan sebesar $0,726<0,05$ yang menunjukkan bahwa empat kelas tersebut homogen.

Selanjutnya adalah menentukan sampel penelitian menggunakan metode purposive sampling area, dimana pemilihan sampel ini bertujuan berdasarkan kriteria tertentu, yaitu sampel yang dipilih harus homogen dan sebagian besar siswa pada kelas tersebut memiliki handphone. Dikarenakan data yang didapatkan sudah homogen maka peneliti dapat memilih dari keempat kelas tersebut, dan didapatkan dua kelas sebagai sampel penelitian yaitu kelas VIII A sebagai kelas eksperimen dan VIII B sebagai kelas kontrol, kedua kelas tersebut memiliki kemampuan yang homogen untuk dijadikan sampel penelitian.

Pada kelas eksperimen yakni kelas yang pembelajaran menggunakan media video sparkol, siswa lebih aktif pada saat pembelajaran, dapat dilihat siswa lebih antusias dalam memperhatikan video yang diberikan karena didalamnya terdapat penjelasan materi disertai suara, gambar, tulisan, animasi yang 
Yolanda., Mahardika., Wicaksono. - Penggunaan Media Video Sparkol ...

bergerak, juga musik yang mampu menarik siswa untuk memperhatikan penjelasan yang ada dalam video tersebut.

Fadhashar dan Indriyanti (2017) mengatakan siswa akan lebih memahami pembelajaran yang tidak hanya menggunakan audio saja namun juga tampilan visual yang diberikan, menghasilkan kesan lebih menarik dan efektif yakni terdapat gambar yang bergerak sehingga mampu membantu siswa menjadi lebih fokus dan berdampak pada pemahaman materi yang akan membantu menuntaskan hasil belajar siswa.

Pada kelas kontrol pembelajaran menggunakan media PPT siswa kurang aktif, dimana dilihat saat guru memberikan pertanyaan siswa kurang merespon, siswa kurang memperhatikan PPT yang didalamnya hanya ada verbal dan gambar. Hal tersebut membuat siswa cenderung bosan dalam pembelajaran.

Selanjutnya, kelas kontrol maupun kelas eksperimen diberikan pre-test yang digunakan untuk mengetahui kemampuan awal siswa. Pada akhir pertemuan siswa akan diberikan tes berupa post-test untuk mengetahui adanya pengaruh dari pemberian treatment pada proses pembelajaran terhadap kemampuan siswa berpikir kreatif.

Hasil pre-test dan post-test kemampuan berpikir kreatif yang disajikan pada Tabel 1.

Tabel 1. Rekapitulasi Nilai Pre-test dan Post-test Kemampuan Berpikir Kreatif Siswa Kelas Kontrol dan Kelas Eksperimen

\begin{tabular}{ccccc}
\hline \multirow{2}{*}{ Data } & \multicolumn{4}{c}{ Kelas } \\
\cline { 2 - 5 } & \multicolumn{3}{c}{ Kontrol } & \multicolumn{2}{c}{ Eksperimen } \\
Jumlah Siswa & 30 & 30 & 29 & 29 \\
Nilai Tertinggi & 50 & 88 & 25 & 94 \\
Nilai Terendah & 20 & 38 & 50 & 50 \\
Rata-Rata & 33,80 & 60,40 & 36,50 & 79,44 \\
\hline
\end{tabular}


Yolanda., Mahardika., Wicaksono. - Penggunaan Media Video Sparkol ...

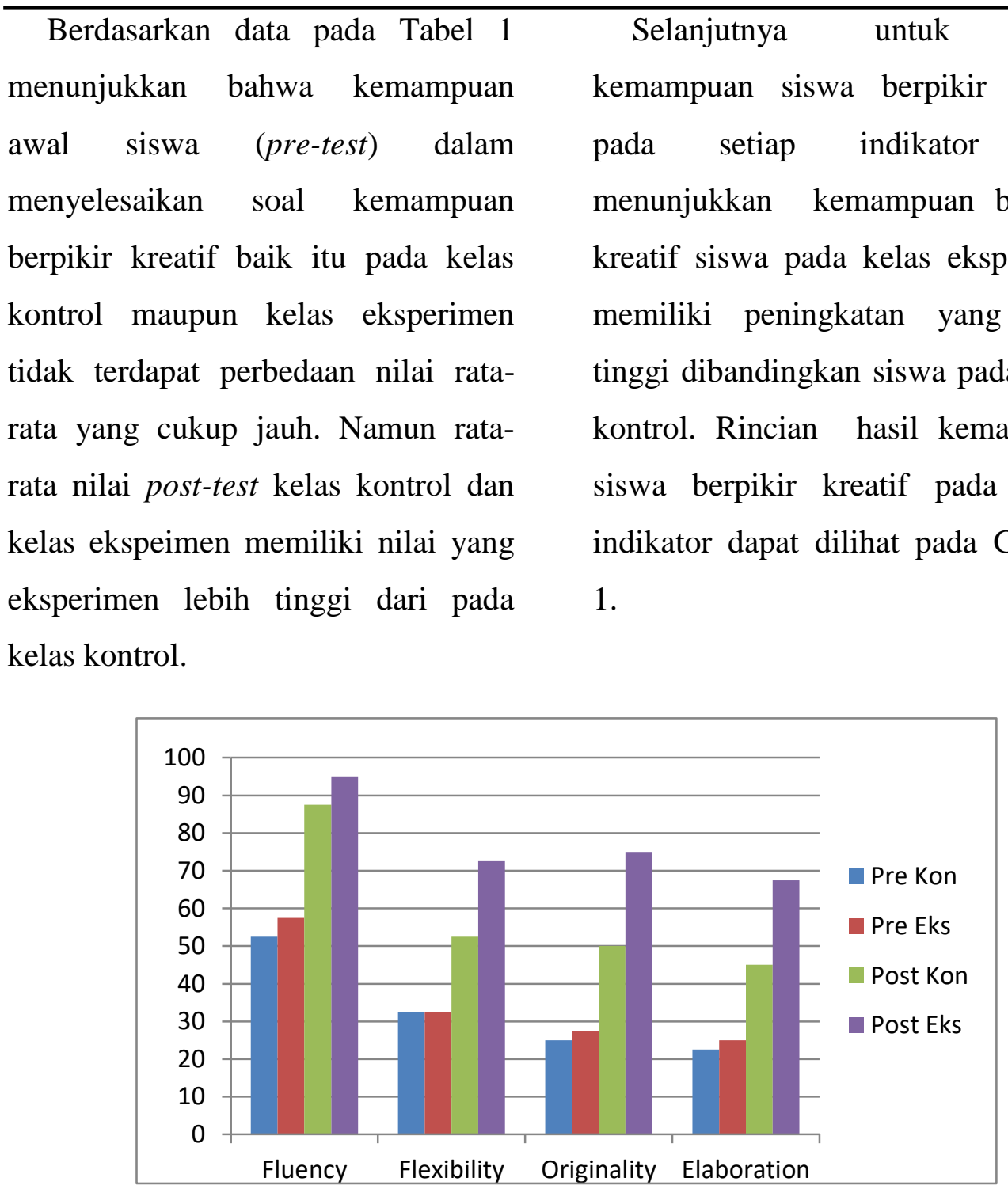

Gambar 1. Nilai Pre/Post Kemampuan Berpikir Kreatif setiap Indikator

Berdasarkan data pada Gambar 1 dapat diketahui terdapat perbedaan hasil tes sebelum pemberian treatment dengan sesudah pemberian treatment, terdapat peningkatan jawaban yang lebih baik dan benar dalam post-test. Hasil pre-test dan post test pada kelas eksperimen dan kelas kontrol diperoleh nilai tertinggi pada indikator fluency dan nilai terendah pada indikator elaborasi.

Hasil pre-test dan post test pada kelas eksperimen diperoleh nilai tertinggi pada indikator fluency, dengan nilai pre-test sebesar 57,5 yang tergolong kategori sedang, 
Yolanda., Mahardika., Wicaksono. - Penggunaan Media Video Sparkol ...

sedangkan pada post-test siswa dari konsep topik pembahasan serta mengalami peningkatan dengan terdapat beberapa siswa yang tidak mendapat nilai rata-rata sebesar 95 dapat menjawab. Siswa pada kelas yang tergolong kategori sangat tinggi.

Pada indikator tersebut siswa dalam menjawab post-test sudah sebagian besar dapat mengerjakan dengan baik, siswa sudah cukup banyak dan bervariasi dalam menjawab, mereka memberikan 5 atau lebih jawaban benar pada setiap soal, pada saat pembelajaran juga siswa dapat menjawab ketika diberikan pertanyaan terkait contoh-contoh dari penerapan tekanan hukum pascal dengan jawaban yang mendekati benar. Sedangkan hasil pre-test dan post-test pada kelas eksperimen diperoleh nilai terendah pada indikator elaborasi, dimana nilai pretest sebesar 25 yang tergolong rendah, sedangkan nilai rata-rata pada posttest siswa mengalami peningkatan dengan mendapat nilai rata-rata sebesar 67 yang tergolong kategori sedang. Hal tersebut dapat dilihat pada saat guru memberikan suatu permasalahan dan meminta siswa untuk memberikan jawaban berupa gagasan ide yang sistematis siswa masih kesulitan menjawab dan keluar eksperimen dikategorikan sebagai siswa yang kreatif dalam menyelesaikan suatu permasalahan, karena setelah diberikan treatment hasil post-test siswa mampu menunjukkan tiga aspek kategori tinggi pada indikator fluency, flexibility, originality.

Selanjutnya hasil pre-test dan posttest pada kelas kontrol menunjukkan nilai tertinggi pada indikator fluency, dimana nilai pre-test sebesar 52,5 yang tergolong kategori sedang, sedangkan pada post-test mengalami peningkatan sebesar sebesar 87,5 yang tergolong sangat tinggi. Pada indikator tersebut siswa dalam menjawab soal juga mengalami peningkatan dilihat dari jawaban posttest siswa sudah mampu memberikan banyak jawaban dalam menyelesaikan permasalahan pada soal, akan tetapi rata-rata pada kelas eksperimen lebih tinggi. Sedangkan hasil pre-test dan post-test pada kelas kelas kontrol juga diperoleh nilai terendah pada indikator elaborasi dengan nilai pretest sebesar 22,5 yang tergolong 
Yolanda., Mahardika., Wicaksono. - Penggunaan Media Video Sparkol ...

sangat rendah, dan pada post-test memiliki nilai sebesar 45 tergolong rendah. Dalam hal ini siswa kesulitan menjawab pertanyaan, dilihat dari hasil jawaban siswa yang belum mengarah pada kesesuaian konsep materi pada gagasan ide yang seharusnya di kembangkan menggunakan pemikiran siswa sendiri, siswa lebih banyak menjawab tidak sesuai dengan konsep.

Dari hasil rata-rata aspek indikator tersebut menunjukkan bahwa siswa pada kelas kontrol dikategorikan siswa cukup kreatif karena setelah diberikan treatment hasil post-test siswa menunjukkan aspek indikator dalam kategori sedang.

Berdasarkan uraian tersebut menunjukkan bahwa siswa kelas eksperimen tergolong kategori kreatif sedangkan siswa kelas kontrol tergolong kategori cukup kreatif dengan hasil nilai tertinggi pada indikator fluency dan nilai terendah pada indikator elaborasi. Hal tersebut sejalan dengan Azhari dan Somakim (2014) yang mengatakan bahwa salah satu penyebab rendahnya kemampuan siswa dalam berpikir kreatif yakni kurangnya kemampuan mengelaborasi, dimana siswa belum mampu untuk memperdalam pemahaman suatu konsep dan mengembangkan konsep tersebut untuk dijadikan solusi dalam menyelesaikan suatu permasalahan.

Berdasarkan penjelasan tersebut, pembelajaran menggunakan media video sparkol lebih efektif dan berpengaruh terhadap kemampuan siswa dalam berpikir kreatif. Hal ini dapat dilihat dari hasil post-test siswa kelas eksperimen yaitu kelas yang pembelajarannya menggunakan media video sparkol menunjukkan kemampuan berpikir kreatif yang lebih tinggi dibandingkan dengan kelas kontrol. Namun, untuk menguji apakah pembelajaran menggunakan media video sparkol berpengaruh signifikan terhadap kemampuan berpikir kreatif siswa di SMP Negeri 3 Rambipuji, maka harus dilakukan uji statistik.

Data pre-test dan post-test kemampuan berpikir kreatif diuji kenormalannya terlebih dahulu untuk mengetahui sebaran data. Berikut merupakan hasil uji normalitas dengan menggunakan bantuan SPSS 24 dapat dilihat pada tabel 2 . 
Yolanda., Mahardika., Wicaksono. - Penggunaan Media Video Sparkol ...

Tabel 2. Hasil Uji Normalitas Nilai Pre-test dan Post-test Kelas Kontrol dan Kelas Eksperimen

\begin{tabular}{lccc}
\hline & \multicolumn{3}{c}{ Kolmogorov-Smirnov $^{\mathrm{a}}$} \\
\cline { 2 - 4 } kelas & Statistic & $\mathrm{df}$ & Sig. \\
\hline pre test kontrol & .153 & 30 & .071 \\
post test kontrol & .156 & 30 & .059 \\
pre test eksperimen & .162 & 29 & .051 \\
post test eksperimen & .158 & 29 & .063 \\
\hline
\end{tabular}

Berdasarkan data yang untuk nilai pre-test dan post-test ditunjukkan Tabel 2 bahwa nilai pembelajaran diadakan post-test signifikansi skor pre-test dan post-test kedua kelas tersebut terdistribusi baik pada kelas kontrol maupun pada normal, sehingga analisis data kelas eksperimen memiliki selanjutnya dapat menggunakan uji signifikansi lebih besar dari 0,05. statistik parametrik yaitu Independent Berdasarkan pedoman pengambilan Sample T-Test. keputusan uji normalitas, maka data

Tabel 3. Hasil Analisis Uji Independent Sample T-Test Kemampuan Berpikir Kreatif

\begin{tabular}{|c|c|c|c|c|c|c|c|}
\hline & & \multicolumn{2}{|c|}{$\begin{array}{c}\text { Levene's Test } \\
\text { for Equality of } \\
\text { Variances } \\
\end{array}$} & \multicolumn{4}{|c|}{ t-test for Equality of Means } \\
\hline & & $\mathrm{F}$ & Sig. & $\mathrm{t}$ & df & $\begin{array}{c}\text { Sig. } \\
\text { (2-tailed) }\end{array}$ & $\begin{array}{c}\text { Mean } \\
\text { Difference }\end{array}$ \\
\hline \multirow[t]{2}{*}{ hasil } & $\begin{array}{l}\text { Equal variances } \\
\text { assumed }\end{array}$ & .025 & .876 & -5.531 & 57 & .000 & -19.04828 \\
\hline & $\begin{array}{l}\text { Equal variances } \\
\text { not assumed }\end{array}$ & & & -5.533 & 56.996 & .000 & -19.04828 \\
\hline
\end{tabular}

Berdasarkan hasil uji Independent samples t-test pada Tabel 3 menunjukkan bahwa nilai F Pada Lavene's test sebesar 0,025 dengan signifikansi sebesar 0,876 atau lebih besar dari 0,05 $(0,876>0,05)$ maka data dapat dikatakan bahwa data tersebut homogen sehingga lajur yang digunakan adalah Equal variances assumed. Ditinjau dari Equal 
Yolanda., Mahardika., Wicaksono. - Penggunaan Media Video Sparkol ...

variances assumed Sig. (2-tailed) pada tabel $t$-test for Equality of Means didapatkan nilai Sig. (2-tailed) sebesar 0,000 atau $(0,000<0,05$ atau lebih kecil dari $0,05(0,000<0,05)$ maka $\mathrm{H}_{0}$ ditolak dan $\mathrm{Ha}$ diterima. Sehingga dapat disimpulkan bahwa ada perbedaan signifikan nilai ratarata kemampuan berpikir kreatif sesudah perlakuan antara siswa kelas eksperimen dan siswa kelas kontrol. Karena kelas eksperimen memiliki nilai yang lebih tinggi dari kelas kontrol maka dapat disimpulkan bahwa pembelajaran menggunakan media video sparkol berpengaruh terhadap kemampuan berpikir kreatif siswa di SMP Negeri 3 Rambipuji.

Berdasarkan nilai post-test dan juga hasil uji statistik pembelajaran menggunakan media video sparkol terbukti lebih efektif dan berpengaruh terhadap kemampuan siswa dalam berpikir kreatif, karena membantu siswa untuk melatih kemampuan berpikir kreatif meliputi fluency, flexibility, elaborasi, dan originality. Hal tersebut dikarenakan media video sparkol yang diberikan menyajikan efek visual yang melekat dalam ingatan siswa dalam jangka panjang karena tampilannya yang dapat menggabungkan gambar, teks, animasi, dan suara yang membuat siswa mengikuti pembelajaran dengan perasaan senang dan tertarik sehingga siswa akan lebih fokus dan materi lebih mudah diingat lagi oleh siswa hal tersebut dapat membantu siswa untuk berpikir lancar (Fluency) dalam menyampaikan gagasan dalam pemecahan masalah.

Video sparkol yang disampaikan menyajikan objek belajar yang lebih konkret dan penyampaian materi pembelajaran lebih terlihat realistik sehingga siswa akan lebih memahami konsep dari materi tersebut, hal itu baik untuk menambah pengetahuan siswa, sehingga mampu membuat siswa menghasilkan variasi-variasi gagasan ide dalam penyelesaian masalah atau jawaban suatu pertanyaan (flexibility).

Video sparkol yang disampaikan mampu menggabungkan suara, gambar, musik, dan desain animasi menarik hal tersebut akan memudahkan siswa untuk memahami materi sehingga membuat siswa mampu untuk memecahkan masalah sesuai dengan konsep yang ada agar 
Yolanda., Mahardika., Wicaksono. - Penggunaan Media Video Sparkol ...

siswa nantinya mampu menggunakan bahasa mereka sendiri sesuai dengan pemahaman konsep yang mereka dapat (elaborasi dan originality).

Hal ini didukung oleh penelitian Apsari et al (2018) yang menyatakan bahwa pembelajaran menggunakan video sparkol mampu membuat siswa lebih termotivasi dan antusias dalam merangsang pemikirannya untuk memecahkan suatu permasalahan, karena pembelajaran menggunakan video sparkol mampu menyajikan obyek belajar yang lebih kongkret dan penyampaian materi pembelajaran lebih terlihat realistik sehingga baik untuk menambah pengetahuan siswa.

Tampilan video sparkol tersebut dapat dilihat pada gambar 1. Hasil penggunaan media video sparkol sebagai video interaktif dalam kegiatan pembelajaran ini sangat efektif, hal ini sejalan dengan penelitian Kurniati et al. (2018). Hal ini dikarenakan video sparkol mampu menyajikan obyek belajar secara konkret atau pesan pembelajaran secara realistik, sehingga membantu untuk meningkatkan kemampuan berpikir kreatif (Kurniati et al., 2018).

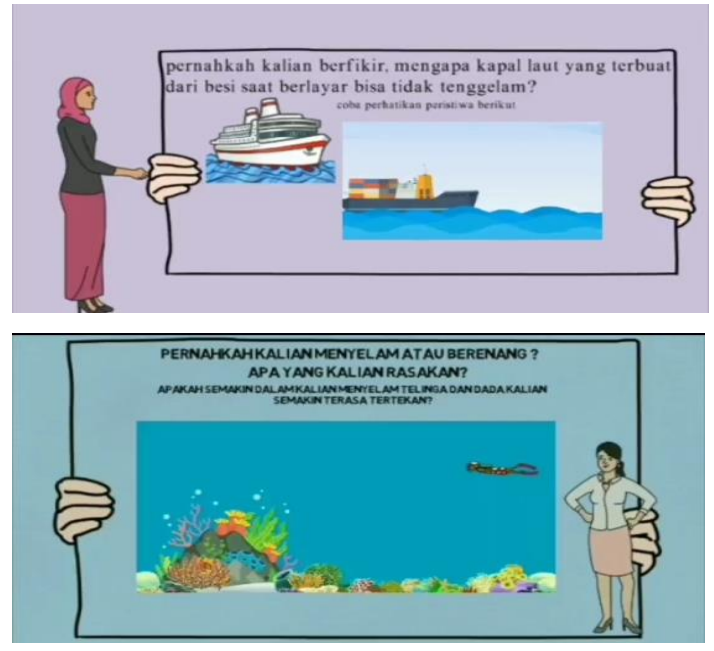

Gambar 1. Tampilan Video Sparkol

\section{KESIMPULAN DAN SARAN}

\section{Kesimpulan}

Nilai signifikansi post-test kelas eksperimen lebih tinggi dari kelas kontrol, serta hasil analisis data menunjukkan kemampuan berpikir kreatif memiliki hasil 0,000 atau $\leq$ 0,05 yang dapat disimpulkan bahwa 
Yolanda., Mahardika., Wicaksono. - Penggunaan Media Video Sparkol ...

terdapat pengaruh signifikan penggunaan media video sparkol terhadap kemampuan berpikir kreatif siswa pada pembelajaran IPA di SMP.

\section{Saran}

Berdasarkan hasil penelitian yang telah dilakukan, saran yang dapat diajukan yakni bagi guru dalam kegiatan pembelajaran media video sparkol dapat dijadikan alternatif sebagai media pembelajaran IPA yang dapat mengembangkan kemampuan berpikir kreatif siswa menjadi lebih baik.

\section{DAFTAR PUSTAKA}

Abdurrozak, R., \& Jayadinata, A. K. (2016). Pengaruh Model Problem Based Learning Terhadap Kemampuan Berpikir Kreatif Siswa. Jurnal Pena Ilmiah, 1(1), 871-880.

Amtiningsih, S., Dwiastuti, S., \& Sari, D. P. (2016). Peningkatan kemampuan berpikir kreatif melalui penerapan guided inquiry dipadu brainstorming pada materi pencemaran air. In Proceeding Biology Education Conference: Biology, Science, Enviromental, and Learning (Vol. 13, No. 1, pp. 868-872).

Pamungkas, A. S., Ihsanudin, I., Novaliyosi, N., \& Yandari, I. A.
V. (2018). Video pembelajaran berbasis sparkol videoscribe: Inovasi pada perkuliahan sejarah matematika. Prima: Jurnal Pendidikan Matematika, 2(2), 127-135.

Arikunto, S. 2011. Prosedur Penelitian (Suatu Pendekatan Penelitian). Jakarta: PT. Rineka Cipta

Azhari, A., \& Somakim, S. (2014). Peningkatan kemampuan berpikir kreatif matematik siswa melalui pendekatan konstruktivisme di kelas VII sekolah menengah pertama (SMP) negeri 2 Banyuasin III. Jurnal Pendidikan Matematika, 8(1), 1-12.

Fadhashar, R., Indriyanti, D. R., \& Lisdiana, L. (2017). Penerapan Model Guided Note Taking dengan Video Pada Pembelajaran Sistem Saraf di SMP. Journal of Biology Education. 6(1): 19-25.

Faelasofi, R. (2017). Identifikasi kemampuan berpikir kreatif matematika pokok bahasan peluang. JURNAL e-DuMath, $3(2)$.

Harefa, Darmawan., \& Sarumaha, Muniharti. 2020. Teori Pengenalan Ilmu Pengetahuan Alam Pada Anak Usia Dini. Banyumas: Penerbit Embrio.

Huwaida, H. 2019. Statistika Deskriptif. Banjarmasin: Poliban Press.

Kurniati, S. Rohayati., \& G. G. Gunawan. (2018). Tinjauan Teoretis Pembelajaran Berbasis Videoscribe Dalam 
Yolanda., Mahardika., Wicaksono. - Penggunaan Media Video Sparkol ...

Meningkatkan Kemampuan

Berpikir Kritis dan Kreatif pada

Siswa SMU. Prosiding SNTP.

PKM Uika Bogor

Lailiyah, Q., \& Suliyanah. (2018).

Profil Keterampilan Berpikir

Kreatif Ilmiah Siswa Pada Materi

Momentum Dan Impuls Kelas XI

SMA Negeri 1 Tarik Sidoarjo. Jurnal Inovasi Pendidikan Fisika. 7(1): 47-50.

Mayarni, \& Y. Yulianti. (2020). Hubungan antara Kemampuan Berpikir Kritis dengan Kemampuan Berpikir Kreatif Siswa pada Materi Ekologi. Journal of Science Education. 4(3): 39-45.

Mulyadi, D. U., \& Wahyuni, S. (2016). Pengembangan media flash flipbook untuk meningkatkan keterampilan berfikir kreatif siswa dalam pembelajaran IPA di SMP. Jurnal Pembelajaran Fisika, 4(4), 296-301.

Munandar, U. 2009. Pengembangan Kreativitas Anak Berbakat. Jakarta: Rineka Cipta.

Permatasari, R. D., \& Rosdiana, L. (2018). Keefektifan Media KIT
Hidrostatis untuk Meningkatkan Hasil Belajar Siswa Pada Materi Tekanan Zat Cair. Pensa EJurnal: Pendidikan Sains, 6(02).

Romadhoni, I., Mahardika, I. K., \& Harijanto, A. (2017). Penerapan model pembelajaran problem based learning (PBL) disertai media $C D$ interaktif terhadap hasil belajar dan aktivitas belajar siswa pada pembelajaran fisika SMA di kabupaten Bondowoso. Jurnal Pembelajaran Fisika, 5(4), 329-336.

Susiningrum, D. (2018). Pengembangan Instrumen Penilaian Kemampuan Berpikir Kreatif Pada Mata Pelajaran Ekonomi Kelas X SMA Hang Tuah 1 Surabaya. Jurnal Pendidikan Ekonomi (JUPE), 6(3).

Wicaksono, I., dan Indrawati. 2019. Videoscribe-Sparkol Sebagai Media Pembelajaran TPACK. Jember: Pustaka Abadi.

Yusuf, A. M. 2017. Metode Penelitian: Kuantitatif, Kualitatif, dan Penelitian Gabungan. Jakarta: Kencana. 